\title{
CDH1 Gene Mutation
}

National Cancer Institute

\section{Source}

National Cancer Institute. CDH1 Gene Mutation. NCI Thesaurus. Code C150473.

A change in the nucleotide sequence of the $\mathrm{CDH} 1$ gene. 